This is an Open Access article, distributed under the terms of the Creative Commons Attribution licence (http://creativecommons.org/licenses/by/4.o/), which permits unrestricted re-use, distribution, and reproduction in any medium, provided the original work is properly cited.

doi:10.1017/So144686X160oo313

\title{
Addressing the ageing workforce: a critical examination of legal policy objectives and values in the United Kingdom
}

\author{
ALYSIA BLACKHAM*+†
}

\begin{abstract}
Population ageing is a key challenge confronting European policy makers. Ageing is a complex issue, requiring a value-driven approach to law and policy. However, there has been limited consideration of what values are driving ageing law and policy in the European Union, or if these values are appropriate. Drawing on an empirical study of United Kingdom (UK) legal policy documents, this paper identifies and critiques the primary values and objectives driving ageing law and policy in the field of employment. It is argued that the values driving UK law and policy are often contested, contradictory and under-defined, and there has been limited thought given to how they should be prioritised in the event they conflict. Thus, there is a serious need to reconsider the approach to age and employment taken by policy makers, and to clarify better the key values on which law and policy rest.
\end{abstract}

KEY WORDS - age, employment, policy, values, equality, United Kingdom.

\section{Introduction}

The population in the European Union (EU) and United Kingdom (UK) is 'ageing rapidly' (Select Committee on Public Service and Demographic Change 2013: 7; see also D'Addio, Keese and Whitehouse 2010: 613-4). It is projected that, by 2025, more than 20 per cent of Europeans will be aged 65 or over (European Commission 2013). Population ageing will have consequences for industry and government services, including

* Norma Elder Law Research Environment at the Law Faculty, Lund University, Sweden.

$\dagger$ Melbourne Law School, University of Melbourne, Australia.

$\$$ Faculty of Law, University of Cambridge, UK. 
housing, pensions, health and social care, and employment. Given this complexity, law and policy to address ageing will require value judgements and difficult decisions about 'what-ought-to-be', to help develop an appropriate management strategy (Rittel and Webber 1973: 159). However, there has been limited consideration of what values are driving ageing law and policy in the EU, or if these values are appropriate. Without explicit acknowledgement and discussion, values remain hidden and underdetermined. In democratic societies, it is desirable that value judgements be explicitly made and be open to discussion and contestation, particularly given the presence of many stakeholders with different priorities and values (Camillus 2008: 100).

To fill this gap, this paper reviews government documents and policy statements to identify and critique the values driving UK ageing law and policy in the field of employment. Drawing on qualitative and quantitative content analysis, six key objectives that underpin UK laws are identified. It is argued that these values remain indeterminate and have multiple (often contradictory) meanings in government policy documents. Further, scant thought has been given to how conflicting objectives (or conflicting interpretations of different objectives) should be reconciled or managed. Therefore, there is a need to seriously reconsider the values that should inform law in this area.

\section{Values in policy}

'Values' are defined as 'principles, or criteria, for selecting what is good (or better, or best) among objects, actions, ways of life, and social and political institutions and structures' (Schwartz 1993: 155). Values are 'non-empirical that is, not directly observable - conceptions of the desirable, used in moral discourse, with a particular relevance for behaviour' (van Deth and Scarbrough 1998: 22). Values can therefore exist and operate at multiple levels, ranging from individuals, to institutions, to society as a whole (Schwartz 1993: 155).

Values are inherent in policy decisions and legal developments that 'reflect the acceptance or rejection of certain values; represent attempts to implement values into policies; or at least reflect the frequent difficulty of arriving at consensus about the status of particular values' (Bartanen 1982: 19). Values offer a 'comparatively neutral' form of 'normative guidance' for policy formation (Giacomini et al. 2001: 8). At the same time, values can be difficult to 'pin down' in policy analysis and development (Giacomini et al. 2001: 16). While all pervasive, values can be difficult to identify and rigorously evaluate, often becoming embedded in policy 
documents rather than being explicitly acknowledged (Giacomini et al. 2001: 18).

While policies reflect the acceptance of certain values, these values are not likely to be uniformly accepted across society. Indeed, values are likely to be contested, and different values may gain the support of different policy actors. Thus, Jenson (1989: 238) has argued that the universe of political discourse is the site of a 'discursive struggle' between different actors seeking representation and different meaning systems seeking legitimacy. Similarly, Boltanski and Thévenot (2006) have argued that there are multiple, interacting worlds with different conceptions of the common good and higher worth that might manifest in political discourse, including the civic world, which focuses on the sovereign and convergence of wills; the industrial world, which focuses on productivity and efficiency; and the market world, with its emphasis on wealth (Boltanski and Thévenot 20o6: 107-8, 185, 190, 204-5; see also Ebbinghaus and Whiteside 2012: 269-70). Individuals can manifest in different worlds, raising the likelihood of a confrontation or clash between two worlds, where the reality of the common good is contested (Boltanski and Thévenot 2006: 216, 223). ${ }^{1}$

According to Boltanski and Thévenot (2006: 37-40), disputes about values are resolved via legitimate forms of agreement, which represent consensus on the relative importance of societal values and ideas of the 'common good'. While multiple principles of agreement might exist in a complex society, the appeal to the common good reduces this plurality to a single principle of justification (Boltanski and Thévenot 2006: 78). Where this agreement is challenged or unsettled, a process of testing can be used to settle disagreements via an appeal to the common good (Boltanski and Thévenot 20o6: 137-8). In this context, policy documents could be seen as reports of the process of justification and testing that is associated with resolving disputes on societal values.

Rather than rely on a process of testing, it might be possible to prevent a clash of worlds and values via three key mechanisms. First, particularly in situations that are oriented towards judgement or justification (such as a public statement of position), policy makers might set up a situation that 'holds together', where any incongruities between worlds and values are minimised (Boltanski and Thévenot 20o6: 228-9). Second, a compromise might be put forward to suspend a clash without settling it, by relying on a test from one world over the other (Boltanski and Thévenot 2006: 277). Compromises suggest the possibility of compatibility through a common good that transcends and includes both worlds (Boltanski and Thévenot 2006: 278; see similarly Jessop 1997: 112-3). However, compromises are fragile, and a clash can always be reactivated (Boltanski and Thévenot 2006: 278). Third, then, attempts might be made to minimise 
any clash via composite items, which seek to stabilise the compromise (Boltanski and Thévenot 2006: 278-9). This may be achieved through the use of ambiguous terms, which straddle multiple worlds and can adopt different meanings in different contexts (Boltanski and Thévenot 2006: 280; see also Karppinen and Moe 2014). The interpretation of ambiguous terms generally happens on a case-by-case basis, drawing analogies with previous cases to avoid confronting value conflicts head-on (Thacher and Rein 2004: 476-8o).

In areas of compromise, we are likely to see frequent repetition of tests to rearticulate and reaffirm the common good and hierarchies of worth (Boltanski and Thévenot 2006: 283). Indeed, in a complex policy environment, frequent communications of this nature can act as guidance, or a form of co-ordinated context-steering, which help to reorient and modify the self-understanding of policy actors of their interests and options, and hence their preferences and expectations for particular policy solutions (Jessop 1997: 110). Thus, communication is a key source of legitimation for governments, and the state's influence depends to a large extent on its role as a collector and mediator of information (Jessop 1997: 117). Further, government communication can construct and define the objects that require governing (Jessop 1997: 124; see also Avsar 2014; Thévenot 2011) - that is, to define and delimit the regulatory problem at hand. The role of communication can arguably extend even further, to reconstruct the ways authorities, governments and even those being governed see and perceive themselves, ultimately transforming the objects of regulatory action (here: the aged) so they voluntarily embrace certain choices and behaviours (in this case, for example, by continuing on working) (Soss, Fording and Scram 2011: 8-9; see also Dean 2010: 43-4). At the same time, government discourses can operate at multiple levels: Dean (2014: 153) has described the tendency of neoliberalism to have a 'doctrine of double truths, of truths that can be expressed differently in relation to different audiences'. Thus, 'truths' can be crafted differently for different audiences and for different places and contexts, with one set of 'truths' for the public, and another for political elites (Dean 2014: 153). It is therefore important to be attuned to the intended audience of policy documents, to ascertain which 'truth' might be communicated and for what purpose.

The significance of policy discourse in shaping policy outcomes is illustrated by Schram's (1999) analysis of social welfare policy in the United States of America (USA). Schram argues that the use of a 'contract' metaphor to ground social policy has operated to reshape and infect policy with particular biases (Schram 1999: 7), including by encouraging a focus on personal responsibility that disadvantages those in need of assistance (Schram 1999: 8). The liberal sub-text of government policy is reinforced 
by signs, symbols and images which replicate existing power relationships (Schram 1999: 8) and privilege white men (Schram 1999: 26). In this discourse, certain needs are de-legitimated, and others are affirmed, in a way that commodifies individuals as a 'piece of property worthy of investment' (Schram 1999: 11-12, 18). Similarly, Dobrowolsky and Jenson's (2004) analysis of Canadian citizenship discourses has shown how a shift in discourse focus, away from women's rights and towards a focus on children, has excluded women's voices from the political agenda.

\section{UK law and policy developments regarding ageing}

This analysis highlights the importance of considering how values are embedded in policy documents, and shape and influence policy outcomes in different substantive areas (though see Dean 2010: 45-6). While some studies have explicitly considered the values inherent in particular policy discourses (in relation to ageing in the USA and Canada, see Clark 1993; in relation to health policy, see Giacomini et al. 2001), this has not extended to ageing law and policy in the UK. While Bernard and Phillips have argued that 'an explicitly articulated value base' is 'crucial to the establishment of this new policy agenda for ageing in tomorrow's Britain' (2000: 34), no UK government has developed a vision or coherent strategy to address ageing (Select Committee on Public Service and Demographic Change 2013:8), and legislative and policy interventions remain piecemeal and reactive in nature (see Bernard and Phillips 2000: 40). Therefore, it is timely to consider what values do and should inform UK law and policy on ageing.

Since 2000, legislative interventions relating to age and employment have primarily focused on preventing age discrimination in the workforce. UK legislation in this area was driven by Council Directive 20oo/78/EC of 27 November 2 ooo establishing a general framework for equal treatment in employment and occupation ('the Framework Directive'), which gives specific expression to the general principle of non-discrimination on the grounds of age. ${ }^{2}$ The Framework Directive was implemented in the UK by the Employment Equality (Age) Regulations 2006 (UK) SI 2006/1031 ('the Regulations'), and later consolidated into the Equality Act 2010 (UK) c 15 ('the Act'). The Act prohibits direct and indirect discrimination, harassment and victimisation in the workplace on the grounds of age during recruitment, in setting the terms of employment, deciding to award promotions and provide training, and in dismissal (s 39). However, less favourable treatment on the grounds of age is not discrimination if the treatment is shown to be 'a proportionate means of achieving a legitimate aim' (s 13(2)). This exception does not 
apply to any other protected characteristics. Indirect discrimination may also be justified using the same test (s 19(2)).

Compulsory retirement has been a key focus of age discrimination policy in the UK. Indeed, mandatory retirement is a major area in which employers might seek to justify direct age discrimination (see Blackham 2016). Since its introduction in 2006, UK age discrimination legislation has always provided scope for employers to adopt a retirement age for their workforce. However, the national default retirement age ('DRA') of $6_{5}$ created by the Regulations was abolished by the Employment Equality (Repeal of Retirement Age Provisions) Regulations 2OI I (UK) SI 2011/1069 ('2011 Regulations'). Employers may still implement an employerjustified retirement age ('EJRA') so long as it can be objectively justified as a proportionate means of achieving a legitimate aim. However, there is significant legal uncertainty regarding when an EJRA will be 'justified'.3

To support older workers in employment, a right to request flexible working was introduced for all employees (including older workers) with 26 weeks' service from 30 June 2014.4 Employers must deal with these requests in a 'reasonable manner', but can refuse an application if they have a 'good business reason' for doing so. 5 While the right to request is a 'weak' piece of legislation (Croucher and Kelliher 2005: 507), it may help to change employers' attitudes towards flexible working.

Finally, the UK government has introduced a number of programmes to address attitudes towards older workers, including: the Age Positive campaign (launched in 2000) to 'tackle ageism in the workplace' by raising awareness of the 'business benefits of recruiting and retaining workers aged over $5^{\circ}$ ' and promoting good employer practice (Department for Work and Pensions (DWP) 2009a: 31); the Everyday Ageism Project, which aims to raise awareness of ageism by encouraging people to share their experiences of ageism online; ${ }^{6}$ support for the Age Action Alliance, an independent partnership of public, private and voluntary organisations 'working together [to] combine our thinking, experience and diverse skills to improve the lives of older people' (Age Action Alliance n.d.); and the appointment of a Business Champion for Older Workers, responsible for 'making the case for older workers within the business community and challenging outdated perceptions' (DWP 2014a).

While there has been a fair amount of legislative and policy activity in the area of ageing and employment, and substantial academic discussion of these developments, there has been only limited consideration of what these measures are trying to achieve, and if these objectives or values are appropriate (Bisom-Rapp and Sargeant 2011 ; see e.g. Fredman 201 1; Fredman and Spencer 2003; Loretto, Vickerstaff and White 2009; Sargeant 2004, 2006, 2008; Vickers and Manfredi 2013; Vickerstaff, Cox and Keen 2003). This paper will explore this gap. 


\section{Method}

A two-stage research design was employed to identify, clarify and evaluate the values underlying government policy in the area of ageing and employment. In the first phase, the study examined the values evident in 19 government policy documents using qualitative content analysis. The topics of study were limited to ageing and employment, but excluded documents relating solely to pensions and social security. 7 Phase 2 tested the relative importance of the identified values, as measured by frequency of use, via quantitative content analysis of the same documents.

\section{Phase I: Qualitative content analysis}

In Phase 1, qualitative content analysis was employed to analyse core documents relating to UK ageing law and policy (Webley 2010: 941). This methodology is similar to legal doctrinal research, particularly in its focus on textual analysis (see also van Hoecke 2011:4). However, it differs in two key ways. First, content analysis can be applied to a broader range of texts than doctrinal analysis, which typically focuses on legal texts (such as cases and legislation). Second, content analysis analyses themes in texts, whereas doctrinal analysis generally seeks to harmonise, rationalise or systematise legal texts (see van Hoecke 2011: 11-17).

Qualitative content analysis involves the identification, coding and categorisation of documents (Patton 1990: 381 ). This process facilitated the identification of values - detecting 'what is' (see Krippendorff 2013:57) and enabled the mapping and contextualisation of the themes or values (Webley 2010: 942). Qualitative coding of this nature is particularly well suited to developing and examining values inherent in legal and policy documents (Webley 2010: 945).

This phase of the research was undertaken in three parts. First, the universe of documents to be analysed was identified. This included government policy documents and position statements. Government documents perform an important expressive function, articulating and justifying legal and policy developments as the by-products of on-going conversations about age and employment (Krippendorff 2013: 77). Therefore, these documents formed a worthwhile and useful universe for analysing legal and political values.

Second, the sample of texts for analysis was determined as being UK government policy statements and responses to consultation between the years 2000 and 2014. 'Government' was defined to include materials authored by government departments, but not non-departmental public bodies (such as the Equality and Human Rights Commission or Acas), parliamentary 
committees or commissions, or research reports or statistical documents that were not representative of government values. Documents within this sample were identified via a literature review, internet searches, review of government websites, and discussions with government and public body representatives. ${ }^{8}$ This process was complex, as many policy documents are removed from public circulation and taken off the internet upon a change of government, although they may be sourced from archival websites. 9 Every effort was made to ensure the sample was comprehensive. ${ }^{10}$ Nineteen documents were ultimately sourced (Department for Culture, Media and Sport and Government Equalities Office 2013; Department of Business, Innovation and Skills (BIS) 2010, $2011 a, 2011 b$; Department of Trade and Industry (DTI) 2003, 2005; DWP 2009 $a, 2009 b, 2013,2014 b$; Government Equalities Office 2008; HM Government 2005, 2008, 2010, 2012, 2013 ; HM Treasury 2008; Performance and Innovation Unit 2000; Social Exclusion Unit 2006).

Third, using NVivo software to ensure consistency, efficiency and thoroughness of data analysis (Weitzman 2003: $3^{16-17}$ ), the texts were inductively coded by the researcher using themes derived from the literature and the documents themselves (Ryan and Bernard 2003: 275-6). Data were initially coded line-by-line to break it into its constituent parts, then consolidated and synthesised through focused or thematic coding (Charmaz 20o6: 46, 50, 57). Constant comparative methods were utilised at all levels of analysis (Charmaz 2006: 54). Using these linkages, broader theories were constructed to reflect the data collected (see Charmaz 20o6: 10).

\section{Phase 2: Quantitative content analysis}

The categories developed through qualitative analysis of the documents were further validated via quantitative content analysis (see Ryan and Bernard 2003: 278). This form of analysis assumes that the most frequently occurring words reflect the authors' greatest concerns (Weber 1990: $5^{1}$ ), as repeated words serve to reinforce and reiterate key ideas. In this study, quantitative analysis offered insights into the priority of different values in government policy, revealing 'what is important' via an assessment of frequency (see Krippendorff 2013:57).

Using NVivo, the sample of documents was coded to look at the occurrence of both (a) specific terms or phrases, via word frequency lists, and (b) sets of words and phrases, or category counts, drawing together multiple phrases and words for analysis where they were assumed to have similar meanings or connotations (Weber 1990: 12). The derived terms and sets were informed by and derived from the results of the qualitative content analysis, and are detailed in Table 1. 


\section{Alysia Blackham}

T A B LE 1. Results of frequency analysis

\begin{tabular}{|c|c|c|}
\hline Value or objective & Search terms & Frequency $^{1}$ \\
\hline \multirow[t]{8}{*}{ Sustainability } & Economic & 230 \\
\hline & Labour market & 216 \\
\hline & Sustainable & 145 \\
\hline & Labour supply & 33 \\
\hline & Prosperity & 26 \\
\hline & Shortage & 2 \\
\hline & Labour demand & 2 \\
\hline & Total & $6_{54}$ \\
\hline \multirow[t]{10}{*}{ Adequacy } & Income & 320 \\
\hline & Savings & 147 \\
\hline & Poverty & $14^{1}$ \\
\hline & Security & 128 \\
\hline & Adequate & 26 \\
\hline & Living standards & 9 \\
\hline & Hardship & 2 \\
\hline & Good life & 1 \\
\hline & Comfortable retirement & 1 \\
\hline & Total & 775 \\
\hline \multirow[t]{15}{*}{ Equality } & Equality & $65^{2}$ \\
\hline & Opportunity & 573 \\
\hline & Discrimination & $5^{00}$ \\
\hline & Inequality & 173 \\
\hline & Fair & 124 \\
\hline & Barriers & 123 \\
\hline & Diversity & 102 \\
\hline & Assumption & 37 \\
\hline & Ageism & 27 \\
\hline & Equity & 25 \\
\hline & Stereotypes & 25 \\
\hline & Prejudice & 23 \\
\hline & Equal treatment & 13 \\
\hline & Judgement/judgment & 5 \\
\hline & Total & 2,406 \\
\hline \multirow[t]{14}{*}{ Social inclusion } & Health & 784 \\
\hline & Active & 482 \\
\hline & Participate & $25^{2}$ \\
\hline & Exclusion & 245 \\
\hline & Integration & 119 \\
\hline & Networks & 117 \\
\hline & Isolation & 107 \\
\hline & Loneliness & 48 \\
\hline & Wellbeing & 45 \\
\hline & Interaction & 26 \\
\hline & Cohesion & 11 \\
\hline & Disillusion & 6 \\
\hline & Society at ease with itself & 2 \\
\hline & Total & 2,244 \\
\hline \multirow[t]{6}{*}{ Solidarity } & Younger & 122 \\
\hline & Balance & 64 \\
\hline & Generations & $3^{6^{3}}$ \\
\hline & Distribution & 25 \\
\hline & Intergenerational & 17 \\
\hline & Lump of labour & 5 \\
\hline
\end{tabular}


T A в LE 1 . (Cont.)

\begin{tabular}{|c|c|c|}
\hline Value or objective & Search terms & Frequency $^{1}$ \\
\hline \multirow{9}{*}{ Organisational efficiency } & Block jobs & 1 \\
\hline & Fewer jobs & 1 \\
\hline & Total & 271 \\
\hline & Benefit & 861 \\
\hline & Business & $44^{\circ}$ \\
\hline & Cost & 290 \\
\hline & Flexibility & 201 \\
\hline & Performance & $14^{6}$ \\
\hline & Productivity & 133 \\
\hline \multirow{20}{*}{ Choice } & Burden & 61 \\
\hline & Efficient & $5^{1}$ \\
\hline & Profits & 24 \\
\hline & Unnecessary & 17 \\
\hline & Red tape & 13 \\
\hline & Expertise & 9 \\
\hline & Regulatory failure & 5 \\
\hline & Inflexible & 4 \\
\hline & Inefficient & 2 \\
\hline & Total & 2,257 \\
\hline & Individual & 439 \\
\hline & Want & 285 \\
\hline & Choice & 182 \\
\hline & Options & 132 \\
\hline & Forced & 127 \\
\hline & Like & $106^{4}$ \\
\hline & Wish & 88 \\
\hline & Choose & 53 \\
\hline & Freedom & 39 \\
\hline & Total & $1,45^{1}$ \\
\hline
\end{tabular}

Notes: 1. Frequencies were calculated using stem words (e.g. a search for sustainable would also include sustainability, etc.). 2. For this term, 'equaled' and 'equally' were manually excluded from the count presented here. 3. Exact term used to exclude 'generated', etc. 4. For this term, 'likely' was manually excluded from the count presented here.

\section{Results}

\section{Values in law and policy}

Using qualitative data analysis, six key objectives or values underlying UK laws relating to ageing and employment were identified: sustainability of the economy, workforce and pension system; adequacy of income for older people; equality for all workers; social inclusion; intergenerational solidarity; and efficiency.

However, the values remained indeterminate and had multiple (often contradictory) meanings in the sample of documents. The sections that follow illustrate how these values were represented and used in the government documents, demonstrating some of the complexity of values-based analysis. 


\section{Alysia Blackham}

Sustainability. The analysis revealed three sustainability objectives within government policies and documents: (a) sustainability of the economy; (b) sustainability of the labour market; and (c) sustainability of pension systems. While these goals are interlinked, the documents presented these objectives in distinct ways.

First, government policy was aimed at securing the sustainability of the economy and society via the employment of older workers. There is concern that the increasing dependency ratio associated with an ageing population (with fewer individuals in employment compared to those outside the labour force) may reduce the number of available workers in the UK, thereby reducing economic output and the state's capacity to pay the costs associated with an ageing population (Loretto, Vickerstaff and White 2005: 7). There is increasing recognition that older people, including those in their sixties and seventies, are more than capable of playing a productive role in the economy (Riley 1988: 149-50; Riley and Riley 1994: 110). In the sampled government documents, older workers were represented as essential for the sustainability of the UK economy, having the potential to make a 'vital contribution' to national prosperity (BIS 2010: 4). It was acknowledged that extending working lives would increase Gross Domestic Product (GDP) (BIS 2010: 8, 2011b: 2), increase tax receipts (BIS 2010: 27) and support the success of 'Britain's businesses' (DWP 2009a: 5). Conversely, early exit from the labour market was viewed as coming 'at great cost to the economy' (DWP 2014b: 3; see also Performance and Innovation Unit 2000: 8). Similarly, employment equality (discussed further below) was seen as having instrumental economic benefits for the UK economy, providing employers with 'the widest labour pool' (Government Equalities Office 2008: 5; see also BIS 2010: 46; DTI 2003: 7; HM Government 2012: 6). Discrimination, on the other hand, was negatively cast, as it 'get[s] in the way of creating prosperity for all' (DTI 2003: 9) and 'costs our economy' (HM Government 2010: 8, see also HM Government 2005: 19). Thus, the retention and employment of older workers was depicted as necessary for the sustainability of the economy and society.

Second, and relatedly, the policies were aimed at sustaining the labour market. With population ageing, labour supply of 2o-64 year olds across the $\mathrm{EU}$ is predicted to decrease by 24.5 million people between 2010 and 205o (European Commission 2011b: 95). Employers will need to look beyond the traditional labour market to supplement their workforce (European Commission $2011 a$ : 10; Schiek 2011: 779), including by employing older workers. In government policy, older workers were valued for their ability to increase 'labour supply' by keeping on working (BIS $2011 b: 7,13$ ). Indeed, older workers were seen as essential for meeting the voracious 
'appetite' of business for workers (DTI 2005: 4) and meeting 'future labour demand' (DWP 2014b: 8; see also BIS 2010: 31 ). Older workers therefore had a key role to play in sustaining the labour market.

Third, the analysis revealed that government policy was directed towards securing the sustainability of the UK pension system. The ageing population may place unsustainable demands on established pension systems as the dependency ratio increases. As the 'baby boom' generation ages, the number of people over the state pension age in the UK is expected to increase by 28 per cent, rising from 12.2 million people in 2011 to 15.6 million people by 2035 (Office for National Statistics (ONS) 2011). Further, people are living longer, which means they are likely to draw on pension entitlements for a longer period of time: some individuals will spend nearly a third of their life in retirement (Riley and Riley 1994: 110). This will obviously place additional pressure on state and private pension schemes, as more people will be entitled to a pension for a longer period, potentially making the existing model of state-backed social insurance unsustainable. At its heart, then, sustainability relates to the ability of governments to finance their social security obligations in the long term (Dorfman and Palacios 2012:4).

The UK state pension system is more sheltered from the effects of an ageing population than other EU and Organisation for Economic Cooperation and Development (OECD) countries (Phillipson 2002: 11-12), being significantly more reliant on private pension provision than other countries, and having the highest proportion of retirement income from private pensions and the lowest public pensions relative to individual income across the OECD (Diepeveen 2012: 10). However, the UK is still facing a recurrent 'pensions crisis' (Harris 2006: 34), with National Insurance Fund expenditure projected to increase from around 5 per cent of GDP in 2008-9 to around 8 per cent of GDP in $2070^{-} 71$ as the result of the ageing population (Government Actuary's Department 2010: 16).

While pension documents were not included in the sample for analysis, sustainability of pension systems was still a recurring value. For pensions, the documents acknowledged that '[a]ffordability and economic stability must be maintained' (HM Government 2005: 9), requiring longer working lives to promote increased pension savings and 'later draw down' by older workers (BIS 2010: 27; see also HM Government 2013: 8). However, this does not obviate individual choice (discussed further below): it was noted that 'the ability to choose when to stop working must also be at the heart of a new system of fair and sustainable pensions' (BIS 2010: 4).

In sum, then, the sampled government documents revealed three interrelated but contrasting sustainability goals, relating to the economy, labour market and pension systems. All three of these goals could ultimately be achieved by extending working lives into old age. 


\section{Alysia Blackham}

Adequacy. Government documents also prioritised and valued securing adequate income for older people. The policies depicted forced and early retirement as causes of poverty and 'financial hardship' (Performance and Innovation Unit 2000: 3; DWP 2014b: 6-7). Work was portrayed as the best means of preventing poverty (HM Government 2005: 9-10), suggesting that extending working lives would allow more people 'to boost their income' (DWP 2009a: 9, 29) and have the opportunity to 'provide for a decent income in later life' (Performance and Innovation Unit 2000: 47). The level of income individuals need to have in old age was variously described as 'adequate' (DWP 2014b: 5, 7; HM Government 2005: 2, 3, 9), 'decent' (HM Government 2005: 9; Performance and Innovation Unit 2000: 45,47 ) and having 'the resources ... to live a good life' (HM Government 2005: xv). This was contrasted with 'poverty' (HM Government 2005: 9-10; Performance and Innovation Unit 2000: 5, 12, 28, 29, 50, 96) and 'financial hardship' (Performance and Innovation Unit 2000: 3). However, there was limited consideration of what this would actually mean in practice, and determining what constitutes an 'adequate' level of benefit is contentious (see e.g. Grech 2013). Based on this sample of documents, 'adequacy' appeared to be linked to either what individuals expect to receive in retirement, or as protection from poverty. These measures are obviously substantially different.

While government documents valued adequacy of income for older workers, it was perceived to be an individual responsibility to earn and/or save for later life: the government would only facilitate individual action, not provide an adequate income to those at risk of poverty. Individuals were explicitly required to 'take personal responsibility for their own wellbeing by working, saving and looking after their health' (DWP 2013; see also DWP 2014b: 3; HM Government 2013: 5), with government action aimed at 'empowering individuals to fulfil their ambitions for later life', including through increased saving (HM Government 2013: 5). Therefore, pension reform was designed to make 'saving for retirement fairer and easier' (DWP 2009a: 7), with individuals expected to work 'as long as is necessary to create the future [they] want' and undertake 'responsible retirement planning' (BIS 2010: 4; DWP 2014b: 4 ).

Thus, while government documents prioritised and valued adequate income for older people, this was seen as an individual responsibility, best secured by extending working lives. Further, what constitutes an 'adequate' income is far from clear.

Equality. Government policy was also oriented towards achieving 'equality', including for older workers. Equality was seen as 'focus[ing] on what individuals can do, instead of making assumptions about capacity based on age' (HM Government 2005: xvi) to create a society 'where people are 
no longer defined by age', and prejudice does not prevent society from benefiting from the skills and experience of older workers (DWP 20oga: 16). This reflects a highly individualised notion of equality. Indeed, the government's 'approach to tackling inequality ... recognises that we are a nation of 62 million individuals', emphasising individual needs (HM Government 2010: 24). In this approach, 'equality is for everyone and is everyone's responsibility' (DWP 2013), redistributing both the focus and the responsibility for equality from government to individuals. While equality was presented as an individual concern, it was linked with economic and social benefits (as noted above), including by 'bring[ing] employers the widest labour pool' and 'help[ing] us compete in a global economy' (Government Equalities Office 2008: 5; see also HM Government 2010: 8). Equality was contrasted with age discrimination, which was represented as having harmful economic, social and individual impacts: age stereotypes, it was noted, 'get in the way of creating prosperity for all' (DTI 2003: 9; see also HM Government 2010: 8).

While advancing equality (and preventing discrimination) was seen as having economic, social and individual benefits, it remains unclear what 'equality' means in this context. There is limited agreement as to what equality entails at both the UK and EU level (O'Cinneide 2011:10-11): equality is not a unitary concept, and what it entails in practice is not straightforward ( see Fredman 2003: 37-46). Equality may span equal treatment, fair distribution, dignity, equal opportunities, and/or full participation and inclusion in social institutions (see Fredman 2003: 37-46, see also Fredman 2011:8-19). While the choice between different conceptions of equality is ultimately a matter for policy and value judgements, not logic (Fredman 2011: 2), UK governments do not appear to have made a choice between competing interpretations. Indeed, Hepple identified seven meanings of 'equality' evident in the Equality Act 2006 (UK) and government equality reviews (Hepple 2011: 13-24).

These varied interpretations of equality continued to be evident in UK government policy (see Fredman 2011). In this sample of documents, 'equality' was variously deemed to mean: (a) equality of treatment, (b) equality of opportunity, (c) dignity, (d) equality of outcomes, and/or (e) fairness.

First, the sampled documents explicitly oriented themselves as being 'built on two principles of equality: equal treatment and equal opportunity' (HM Government 2010: 5). This does not, though, mean 'uniformity' of treatment (HM Government 2010: 9). Rather, it means 'giving everyone an equal right to be treated fairly as an individual' with 'equal opportunity to progress' (HM Government 2010: 9). Thus, positive action was allowed 'to redress disadvantage as well as tackle discrimination' (Government 
Equalities Office 2008: 26). Equality was portrayed as 'unlock[ing] the talents and potential of all [Britain's] citizens' (Performance and Innovation Unit 2000: 3). Again, this is a highly individualised notion of equality, with equality of opportunity emphasising individuals' capacity to 'maximise their potential' (HM Government 2005: 31; see also Department for Culture, Media and Sport and Government Equalities Office 2013; Government Equalities Office 2008: 5) and 'seize opportunities' (HM Government 2005: 31, see also DWP 2009a: 16; HM Government 2008: 5, 6, 2010: 6, 17). The individuals these policies were aimed at were perceived to be industrious, ambitious, with 'effort [and] ability' (HM Government 2010: 5) and capable of maximising opportunities. The government's role was to 'break down the barriers that hold people back' (HM Government 2010: 6), as this idealised individual could then maximise the opportunities available ( see further below).

That said, this individualised notion of equality was also directed towards achieving broader social and economic benefits (as noted above), with equality of opportunity providing individuals with the 'opportunity to contribute to society and to the economy' (Performance and Innovation Unit 2000: 5; see also HM Government 2012: 3). In an equal society, 'everyone, young and old, has the opportunity to play their full part' (Performance and Innovation Unit 2000: 8; see also HM Government 2012: 3). The role for government, then, was to 'promote the opportunity for all to contribute to and share in ... prosperity' (DTI 2005: 4) and to facilitate individuals fulfilling their 'responsibilities' to society (HM Government 2005: xvii). However, while 'opportunity' featured social and economic aspects, it was also linked to individual betterment: individuals should have the opportunity to 'succeed' (Government Equalities Office 2008: 12; HM Government 2010: 6), 'progress' (HM Government 2012: 3), 'improve their lives' (HM Government 2012:4) and to 'live fulfilling, productive lives' (DWP 2ooga: 6), via the 'opportunity to work' and 'participate in the labour market' (BIS 2010: $4,8,32$ ).

Second, while equality of treatment and equality of opportunity were held up as the driving values of UK policy, equality was also valued for its intrinsic or dignity benefits, recognising a 'basic right to be free from prejudice and discrimination' (Government Equalities Office 2008: 5). Equality was represented as helping 'to build a country where all are valued' (Performance and Innovation Unit 2000: 8). However, the documents also depicted a 'right' to equality as entailing a responsibility to contribute back to society, once there was an opportunity to do so (as discussed above).

Third, there was some allusion to equality of outcomes, as documents aspired to 'prosperity for all' (DTI 2003: 9, 2005: 4). Indeed, the 'rights older people can expect' included 'security, an adequate income and 
decent housing' (HM Government 2005: 2). While this sets the bar rather low, it does flag the possibility of equality of outcomes. However, this was largely confined to older policy documents, with limited mention of outcomes in documents published since the election of a ConservativeLiberal Democrat Coalition government in 2010.

Fourth, in some documents 'equality' was linked with 'fairness' (BIS 2010: 26; DTI 2005: 4; Government Equalities Office 2008: 6; HM Government 2012: 4). Equality was seen as 'fundamental to building ... a fair society' (HM Government 2010: 5; see also Government Equalities Office 2008: 5 ) and fairness was intertwined with equality of opportunity: 'It is only fair that those who experience age discrimination should have the same opportunities as others' (DTI 2005: 4). Government policy was therefore aimed at 'ensuring fairness and opportunity for all' (HM Treasury 2008: 4). Indeed, '[e]veryone has the right to be treated fairly' (Government Equalities Office 2008: 5) in 'fairer employment' (HM Government 2005: 16, 2012: 3).

In sum, while equality was a driving value of UK government policy, it is still unclear what 'equality' means in this context. Indeed, equality continues to have multiple, potentially conflicting meanings.

Social inclusion. Social inclusion is intended to 'establish conditions and opportunities that induce all citizens to participate in society and to come to value its institutions and potentials' (Collins 2003: 24). The sampled government documents depicted being unemployed, retired (Social Exclusion Unit 2006: 6o) or excluded from the labour market as key forms and predictors of social exclusion (Performance and Innovation Unit 2000: 5, 29). In contrast, being employed was a way of leading a 'fulfilling' life and contributing to society (Performance and Innovation Unit 2000: 8). While the documents affirmed that governments could help facilitate older workers' participation in employment, social inclusion was ultimately depicted as an individual responsibility (HM Government 2005: 38; see also Social Exclusion Unit 20o6: 66).

Although social exclusion was a key focus of UK policy, what is meant by the term is far from clear (Lister 2000: 37). Indeed, social exclusion remains a contested concept, being 'inherently problematic' (Levitas 2005: 2). At a basic level, social exclusion is concerned with an individual's (lack of) moral integration in society and the breakdown of social ties (Levitas 2005: 21-2). While social exclusion could span a variety of fields, the dominant 'social integrationist' discourse at the EU (and UK) level focuses on economic and social integration through paid work (Levitas 2005: 22). Work is perceived as having social, moral and economic functions (Levitas 2005: 22), promoting wellbeing and enabling autonomy, 


\section{Alysia Blackham}

knowledge and skill development, participation in a workplace community, status, a sense of identity, self-esteem, goals, ambitions and friendships (Collins 2003: 25; Gray 2000: 26). Work and employment are idealised as the key to social inclusion (Stewart 2000: 4). In UK policy, then, social inclusion was depicted as 'play[ing] a full part in society' (Government Equalities Office 2oo8: 16), 'remain[ing] active in society' (HM Government 2008: 6) and 'contribut [ing] actively to society in later life' (HM Government 2008: 6), particularly via work. Work was portrayed as providing personal and health benefits (BIS 2010: 8; DWP 2009a: 29, 2014b: 5), staving off dementia (DWP 2009a: 29), promoting a 'sense of worth' (DWP 2ooga: 9), 'sense of identity' (BIS 2010: 8) and a 'strong sense of purpose' (DWP 2009a: 29). Like 'equality', 'social inclusion' remained an underdetermined and contested value in UK policy.

Solidarity. UK policy documents also promoted intergenerational solidarity as an objective and value. Supiot defines solidarity as a way of conceiving a collective obligation not based on individual consent, family ties or community allegiance (Supiot 2007: 208). More specifically, intergenerational solidarity involves 'each generation recognis[ing] its responsibilities towards the others' (Eurofound 2012:3) and a degree of bonding between individuals of different age groups (Cruz-Saco 2010: 9). Intergenerational solidarity is a form of 'contract across generations', with shared expectations and obligations around ageing and the 'succession of generations' (Bengtson and Oyama 2010: 38 ), grounded in the idea of reciprocity (Izuhara 2010: 5) and intergenerational transfers (Bengtson and Oyama 2010: 36; Lowenstein 2010: 58). Intergenerational solidarity describes a form of social cohesion between generations (Bengtson and Oyama 2010: 35).

The sampled documents explicitly acknowledged the importance of balancing intergenerational needs (HM Government 2005: 2), while also recognising the potential of 'intergenerational balance' to undermine the position of older workers. Indeed, intergenerational solidarity, as embodied in "pressure to make way for "young blood", was depicted as curtailing working lives unnecessarily (Performance and Innovation Unit 2000: 3, 6). Rejecting this stance, the documents emphasised giving older workers 'real choices and opportunities', rather than merely putting pressure on them to 'give way to "young blood" (Performance and Innovation Unit 2000: 3, 6; see also BIS $2011 b$ : 2, 7; DWP 2014b: 3). The documents explicitly rejected the 'lump of labour' fallacy, or the idea that 'shedding' older workers would make way for younger workers (Performance and Innovation Unit 2000: 39-40; see also BIS 2011 b: 2, 7; DWP 2014b: 7-8).

Intergenerational solidarity is therefore beset by contradictions: while ideas of solidarity prevalent since the 197 os required older workers to 
retire (Guillemard and Rein 1993: 474; von Nordheim 2004: 145), ${ }^{11}$ new notions of solidarity require older workers to make a 'continuing and growing contribution' to society (HM Government 2005: 2), including through work. In the documents, individuals were expected to remain in work for longer, 'applying their skills in productive ways' to benefit society and reduce 'financial burdens on younger generations' (DWP $2009 a$ : 57). Thus, we need to reconceive the nature of the 'intergenerational contract' in place in the UK (Butts 2010: 94), and intergenerational solidarity may require changed expectations among older workers regarding when and how they retire (see also Butts 2010: 94; Eurofound 2012: 3). It is therefore unsurprising that government documents saw 'the balance between generations [to be] changing' (HM Government 2008: 2 ). This shifting balance is also noted in the literature (see Bengtson and Oyama 2010: 38-9; Cruz-Saco 2010: 11): indeed, Supiot (2007: 209) argues that solidarity in Western states is undergoing 'a major crisis'. Attempts to reconcile conflict between generations in the documents relied on the universality of ageing:

Everyone has a role to play in this journey towards a new society, because everyone is getting older. Every individual will ultimately be at the centre of preparing better for their own later life, living well in later life, and finding the right support if required. (DWP 2009a: 10)

Therefore, according to the sampled documents, ageing placed obligations on all citizens to manage their own lifecourse. It is unclear whether this approach will enable solidarity to co-exist with generational conflict (Bengtson and Oyama 2010: 37). Thus, intergenerational solidarity embodies an ambivalence towards age and ageing that is yet to be resolved.

Efficiency. Finally, government policies were geared towards securing and protecting organisational efficiency. Efficiency enables businesses to achieve their objectives with low inputs of resources (Rittel and Webber 1973: 158). Therefore, efficiency is fundamentally focused on financial performance and factors such as return on investment. In the documents, the presence of age discrimination in employment was depicted as impairing organisational and social efficiency:

The economy is losing productivity and growth, business is losing profits, employers are losing talent, society is losing a contribution and older people are losing selfesteem and choice. (Performance and Innovation Unit 2000: 8; see also DWP $2014 b: 5,8)$

In contrast, age diversity (as opposed to age equality) was noted as offering 'proven advantages' (HM Government 2005: 20) and 'clear benefits' in 'attracting new business, understanding customers' needs and filling skills 
gaps' (Government Equalities Office 2008: 27; see also DWP 2009a: 16). Thus, older workers were perceived as being 'key players in ... firms' success' (HM Government 2005: v). It was argued that '[s] mart businesses' had already recognised the importance of age diversity (BIS 2010:4), and that the role of government was to 'encourag[e] employers to realise the business benefits of an age diverse workforce' (HM Government 2005: 20).

The documents therefore revealed that UK government policy was geared towards achieving age diversity as a means of increasing organisational efficiency. This reflects the 'business case' for age equality (see Blackham 2016), and epitomises a broader shift towards a 'diversity' approach to equality, and an emphasis in organisations on achieving business and organisational goals via employee diversity (Kirton and Greene 2010: 127). Kirton and Greene (2010: 127) argue that this shift towards 'diversity management' has lessened the focus on social justice that has traditionally underpinned equality approaches in business, replacing it with a new and exclusive focus on the business case for diversity. This approach has significant limitations, not least because equality measures may be abandoned where their economic benefits are in doubt (Malleson 2009: $38_{4}$ ).

As a further means of achieving 'efficiency', government policy under the Coalition government emphasised reducing or eliminating any 'administrative burden' that might be associated with ageing. Indeed, the Coalition government established a 'Red Tape Challenge' aimed at 'reduc[ing] the overall burden of regulation by reducing the "stock" of regulations that are already in place' (BIS $2011 a: 2$ ). In this context, regulation was seen as impairing organisational efficiency and progress. The government's 'vision' for labour law was therefore one of 'minimal intervention by the Government' (BIS $2011 a$ : 4). Again, this reflects a governmental reluctance to actively intervene in the area of ageing, and the tension between 'efficiency' and notions of equality grounded in dignity.

\section{Value priorities and conflicts}

While conflicting values and priorities are typical of complex policy problems, this flags broader issues regarding the relative desirability or prioritisation of values. It is arguable that the documents in this study embody a clash between competing civic, industrial and market worlds (Boltanski and Thévenot 2006: 107-8, 185, 190, 204-5). If this is the case, it is necessary to consider how this clash is to be resolved or managed. There has been very limited consideration of how conflicting objectives (or conflicting interpretations of different objectives) should be reconciled or managed at the EU or UK level (Williams 2010: 681). According to Williams, this has resulted in a: 
lightweight legal approach to how some form of ethically governed decision-making can be effected ... Instead of a balance operating to give effect to values, the exigencies of the market have provided a sort of value-surrogacy. (2010:681)

In UK policy making, market 'needs' or economic values often take priority over other values ( see Fredman 2002: 25), suspending any clash via reliance on market understandings of the common good (Boltanski and Thévenot 20o6: 277). At the same time, there has been limited consideration of why economic concerns should 'trump' other objectives (Fredman 2002: 25 ). Thus, it is necessary to explore in more detail the relative importance and desirability of different values in ageing law and policy, and what this means for the underlying rationale of ageing policy.

Quantitative content analysis was therefore used to interrogate the comparative weight given to different values in the documents, via an assessment of frequency ( see Krippendorff 2013:57). ${ }^{12}$ Table 1 reports the full details of the search terms used and results obtained from the analysis.

If the relative frequency of values is related to their relative importance, it appears that equality, social inclusion and efficiency are far more important in government documents than adequacy, sustainability and solidarity. This is consistent with the qualitative analysis above: government documents appear to minimise the importance of intergenerational solidarity, relying instead on individuals 'contributing' at all ages. Further, if income is an individual responsibility, government documents are likely to be less concerned with adequacy. Similarly, the individualised focus of government policy may minimise the need to consider broader issues of sustainability. This is consistent with a reliance on market understandings of the common good being used to suspend any clash with civic or industrial worlds and values (Boltanski and Thévenot 2006: 277). While this compromise suggests that market understandings of the common good transcend and include different worlds (Boltanski and Thévenot 2006: 278; see similarly Jessop 1997: 112-3), this compromise is inherently unstable and fragile (Boltanski and Thévenot 2006: 278), and is likely to fall apart if subjected to detailed scrutiny.

\section{Analysis and emerging themes}

Three key themes and underlying ideas emerge from this analysis. First, it reveals the conflicting values inherent in ageing law and policy, and the minimal effort that has gone into reconciling conflicting objectives. Yanow (1992: 402) argues that incommensurable values breed 'policy myths', where narratives 'mask tensions between or among incommensurable values' to allow individuals to believe that the conflict has been 


\section{Alysia Blackham}

resolved. Policy myths '[deflect] continued attention from the incompatible, yet equally valued, principles' (Yanow 1992: 402). Indeed, policy myths may help to set up situations that hold together, and minimise any incongruity between values (Boltanski and Thévenot 20o6: 228-9). In the UK, the enduring 'policy myth' used to reconcile conflicting values relates to the idealised older worker. UK policy makers appeared to have envisaged the focus of their policy making as someone who was skilled, ambitious, probably educated, male and undertaking a white-collar role who could 'maximise their potential' (HM Government 2005: 31; see also Government Equalities Office 2008: 5; Department for Culture, Media and Sport and Government Equalities Office 2013) and 'seize opportunities' (HM Government 2005: 31) once government policy meant they were no longer 'held back' (HM Government 2010: 6). Similarly, Estes (2001: 198) argues that a focus on 'productive' ageing 'implicitly accords normative value to aging equated with success'.

The myth of the ideal older worker allowed policy documents to cloak the disjunction between equality and efficiency, and adequacy and sustainability. The ideal older worker could: contribute meaningfully to the economy and to workplace efficiency by exercising their skills and experience; continue working to ease the burden on pension systems and source their own (adequate) income; and only needs to be provided with 'opportunities' to 'succeed', and not be 'held back' (HM Government 2005: 31, 2010: 6). Older workers who fail to meet this ideal reveal the multiple tensions inherent in policy values: if needing additional support or adjustments to remain in or return to the workplace (see Crawford et al. 2010), older workers may impair organisational efficiency, or demonstrate the inadequacy of 'equality of opportunity' for achieving social inclusion (Crawford et al. 2010; see e.g. Muchmore et al. 2003). Indeed, a 2015 report by the UK Business Champion for Older Workers noted that major barriers to later working lives included 'low skills, lack of confidence, inadequate up to date qualifications, long-term health conditions, disabilities and the difficulty of combining work with caring', particularly for older women (Altmann 2015: 9; similarly see DWP 2015). Further, according to ONS data for 2011, nearly two-thirds of UK male workers over state pension age were in high-skill roles, compared with only one-third of female workers over state pension age. The percentage of women in highskill jobs in 2011 dropped from 24 per cent for those under state pension age to 18 per cent for those over state pension age (ONS 2012:3). Thus, women in particular may struggle to match the ideal of the older worker. If organisational efficiency entails the exclusion of these older workers from employment, this will jeopardise sustainability, social inclusion and adequacy of income, particularly given women are already vulnerable to a 
gender pension gap (which has been reported to be as high as 39 per cent across the EU27) (Bettio, Tinios and Betti n.d.; see also Frericks and Maier 20o8). This conflict between different values in UK ageing policy is of significant concern, and may undermine law and policy in practice.

Second, the values underlying UK government policy were all geared towards an individualistic focus, with individual choice mentioned $1,45^{1}$ times in the sampled documents. Choice was seen as something which should be 'achievable at all stages of life, and should underpin all public policies' (HM Government 2005: 3). Removing a national retirement age was seen as an exercise in promoting individual choice and freedom (BIS 2010: 4, 2011 b: 2; DWP 2009a: 31; HM Government 2010: 16, 201 2: 7), and a way of reducing government intervention in the activities of employers and employees. This is entirely consistent with an Anglo-Saxon and neoliberal model of individual rights and freedoms (see Ashkanasy, Trevor-Roberts and Earnshaw 2002): while employees may still retire, this is ultimately an individual decision, which must be negotiated at an individual (not governmental) level. Government policy was focused on providing older workers with choices that were 'real' (Performance and Innovation Unit 20o0: 6, 46), 'informed' (HM Government 2005: 17, 21), 'better' (HM Government 2008: 5, 6) and 'genuine' (Performance and Innovation Unit 2000: 47). Thus, individual choice and freedom sat at the core of government policies (see BIS $2011 b$ : 2; DWP 2014b: 3, 5). This is consistent with the core values evident in UK policy making more generally: indeed, the UK is often regarded as one of the most individualistic countries in the world (Hofstede 2001:215).

While UK law and policy emphasised the importance of individual choice, this brought with it individual responsibility (DWP 2014b: 3). Therefore, a focus on individual choice could rationalise and justify limited government intervention and a minimal governmental role. Clark (1993:487) has noted the significant impact of 'the cultural context of the continuum between individualism and collectivism' in 'defining policy problems and their solutions'. If ageing is defined in individualistic terms, this will have dramatic implications for how society (and government) 'defines a moral obligation to enhance the quality of life of older persons' (Clark 1993: 487). By defining ageing as an individual matter, UK government documents have minimised the moral case for intervening to protect and enhance individual wellbeing, shifting the risks associated with ageing to the individual (see Estes 2001: 194). Thus, individual choice is linked with a responsibility (and financial compulsion) to continue working to maintain a certain standard of living. This may also help to explain the small category count for 'adequacy' in the quantitative content analysis.

The focus on individual choice in the documents also provides support for the 'adult worker model thesis', which posits that social policy is 


\section{Alysia Blackham}

increasingly treating people as individual workers (either actual or potential) (Daly 2011:4-5). In this context, 'choice' is valued and assumed, and work is seen as an expression of individual choice (Daly 2011:4-5). Again, focusing on this form of choice is likely to downplay the importance of social security provision, and support the reduction of old-age pension entitlements, as all individuals are increasingly seen as potential workers who can sustain their own standard of living. In this way, the use of 'choice' in the documents under study has parallels with the use of a 'contract' metaphor in US social welfare policy (Schram 1999: 7). Both ideas encourage a renewed focus on personal responsibility, may serve to disadvantage those in need of assistance (Schram 1999: 8), and reinforce the commoditisation of individuals through (potentially coercive) labour market integration (Schram 1999: 11-12, 18).

Going further, it is arguable that the notion of 'choice' is being used in the documents to stabilise the disjunction and ultimate compromise between market, industrial and civic worlds inherent in ageing policy (Boltanski and Thévenot 2006: 278-9). 'Choice' is sufficiently ambiguous to encompass multiple meanings consistent with multiple world views: in the civic world, choice is about individual rights and autonomy (Boltanski and Thévenot 2006: 325); in the industrial world, choice is associated with integration in the labour market, and the achievement of dignity through potential activity in work (Boltanski and Thévenot 2006: 206); and in the market world, choice is linked to the individual prerogative of pursuing wealth and maximising capital. Thus, the use of 'choice' as a grounding symbol in the policy discourse may serve to cloak, prevent or suspend clashes between the industrial, market and civic ideas driving ageing policy.

The emphasis on 'choice' may also help to explain the enduring similarities between the policy documents over time. While the documents were produced by a range of government departments, and spanned both Labour and Coalition governments, there is remarkably limited disparity between the key values that emerge in the documents, though the interpretation of those values may have shifted over time (see the discussion of equality above) and social inclusion was less prevalent as a value in Coalition documents. Thus, an enduring focus on 'choice' may have reduced any disparity between various governments and institutional actors, creating at least the appearance of a uniform approach to the 'common good' over time. Alternatively, the mentality of 'choice' may have encouraged selfrestraint on the part of the state, and limited the state's involvement as an institutional entrepreneur (Flynn et al. 2014: 549). This could serve to reenforce and exacerbate the path dependence of government policy in this area (Flynn et al. 2014: 549). 
Third, and relatedly, the study reveals that equality, social inclusion and efficiency are far more important in driving ageing law and policy than adequacy, sustainability and solidarity. It is questionable whether this weighting is desirable from a normative perspective. For example, Bernard and Phillips have argued that ageing policy should reflect a commitment to four areas: a positive, intergenerational, lifecourse perspective (moving away from a focus on old age and individuals as burdens, and adopting a more flexible approach to age and ageing); the importance of combating all forms of discrimination; notions of empowerment, citizenship and voice; and critical commentary and action (Bernard and Phillips 20oo: $43-6)$.

Bernard and Phillips's commitments are partly reflected in the values of solidarity, social inclusion and equality. However, the values in government documents reflect a more minimal understanding of these objectives. Further, 'efficiency' does not appear in Bernard and Phillips's list. Similarly, Weller argues that ageing policy needs to focus more on human rights and less on economics, moving to a more resilient policy approach 'stressing justice and universal rights to fair treatment' (Weller 2007: 432 ). Therefore, the broader literature questions the normative value of 'efficiency' as an overriding policy value (see also Hepple 2013) and draws attention to the importance of solidarity and more substantive notions of equality. This is obviously at odds with the findings of this study.

\section{Conclusion}

Ageing is a complex and contested policy area. While there have been legal and policy interventions to respond to the ageing 'challenge' in employment, there has been minimal discussion of what these measures are trying to achieve, and whether these objectives are appropriate. Using qualitative and quantitative content analysis, this study has identified and critiqued six values that permeate government policy documents relating to age and employment in the UK: sustainability, adequacy, equality, social inclusion, solidarity and efficiency. These values are contested, contradictory and under-defined, and government documents show limited consensus regarding how the values should be prioritised in the event they conflict. This reveals the challenges of identifying and normatively assessing values in government policy, and the very real disagreement that remains regarding values in the area of ageing.

This research provides an initial assessment of the values that underlie UK government policy, and offers a preliminary discussion of what values should drive government policy. While this research offers a new, empirically 
informed perspective on an under-theorised area of UK law, it can only be the start of the conversation. Until government values are determined and clarified more rigorously, ageing is likely to remain a complex issue that continues to require deep discussion and debate. The impact of values on the direction and focus of policy debates also requires stronger recognition. Thus, there is significant scope for more detailed and thorough analysis of policy values, both in the UK and internationally.

To effect meaningful and sustainable change to respond to demographic ageing, governments and policy makers must dedicate more attention to clarifying the values and objectives underlying legal reform, and consider how conflicting objectives and values should be reconciled (see Bernard and Phillips 2000: 34). Without this, legal reform will continue to be sporadic and haphazard, without an overall holistic agenda. It is only by articulating and interrogating the values driving ageing law and policy that we can start to critique and challenge their normative desirability. It is essential that we expose, clarify and critique the values underlying law and policy. While this study is confined to the area of ageing in the UK, it has broader implications for legal scholars in other areas and other countries. This value-based approach to analysis may open up new ways to address other complex policy problems, offering new insights for legal scholars working in complex areas of law and policy. A scholarly focus on doctrinal change that ignores the role of values in policy making is pursued at our peril.

\section{Acknowledgements}

This paper was originally presented to the Norma Elder Law Research Environment at the Law Faculty, Lund University, Sweden and the 2015 Law and Society Association Annual Meeting. The author thanks the attendees at those meetings and the reviewers for their constructive comments and feedback. The work on this article was carried out within the Norma Elder Law Research Environment at the Law Faculty, Lund University, Sweden, and with funding from the Marianne and Marcus Wallenberg Foundation. The Marianne and Marcus Wallenberg Foundation played no role in the design, execution, analysis and interpretation of data, or writing of the study.

\section{NOTES}

1 Similarly, Soss, Fording and Scram (2011:5) argue that poverty policy in the USA embodies competing visions of society, and different conceptions of citizenship.

2 Kücükdevici v. Swedex GmbH (C-555/o7) [2009] EUECJ C-555/o7 (9July 2009) [21], [5o]; Mangold v. Helm (C-144/04) [2005] ECR I-9981, [75]. 
3 See Seldon v. Clarkson Wright Ẽ Jakes (A partnership) [2012] UKSC 16 (25 April 2012).

4 Employment Rights Act I996 (UK) c 18 s 8oF; Children and Families Act 2014 (UK) c $6 \mathrm{~s} 131$. This right previously only applied to workers with caring responsibilities.

5 Employment Rights Act 1996 (UK) c 18 s 8oG; Children and Families Act 2014 (UK) c 6 s 132 .

6 See http://www.everydayageism.co.uk/.

7 While the availability and quantum of a pension are key factors in encouraging retirement (Atchley 1982: 276; Fredman 2003: 26; Phillipson 1987: 161; Posner 1995: 141), pension policies are rarely linked to employment issues. The values in pension documents may diverge from those in employment documents, given they generally address social security issues and relate to post-employment matters. The separation of employment and pension policy may be an example of a firewall strategy to avoid value conflicts (see Thacher and Rein 2004: 469-76). Thus, while acknowledging the potential links between pensions and ageing and employment, the exploration of pension policy values was excluded from this study. However, it is intended that this will form the basis of future research, which could usefully be compared with the results of this study.

8 Discussions with government representatives were conducted as part of a broader study considering ageing law and policy in the UK: see Blackham (2016). As part of that study, expert interviews were conducted with representatives from the Department for Work and Pensions and Department of Business, Innovation and Skills; and with representatives from non-departmental public bodies, such as Acas (Advisory, Conciliation and Arbitration Service) and the Equality and Human Rights Commission. Where respondents identified policy documents as part of these interviews, these were included as part of the analysis.

9 See, for example, http://www.cpa.org.uk/cpa/policies_on_ageing.html.

10 Given the overall consistency of view across the different documents (see further below), it is unlikely that any inadvertently omitted documents would fundamentally alter the results.

11 While most prevalent in the late 2oth century, these ideas still endure in some form.

12 However, it is questionable whether values can be 'ranked' in this way. Giacomini et al. (2001: 19) question whether values can be 'weighed' against each other to rank them by their relative importance. Instead, the authors argue that values should be 'fitted' within a specific context, to accommodate and 'size' values within a specific situation. This risks devolving into the existing 'market expediency' approach evident in UK government documents.

\section{References}

Age Action Alliance n.d. Age Action Alliance - Improving Older People's Lives ... Together. Available online at http://ageactionalliance.org/ [Accessed 11 July 2014].

Altmann, R. 2015. A new vision for older workers: retain, retrain, recruit. Report to Government by Dr Ros Altmann CBE, Business Champion for Older Workers, London.

Ashkanasy, N. M., Trevor-Roberts, E. and Earnshaw, L. 2002. The Anglo Cluster: legacy of the British empire. Journal of World Business, Leadership and Cultures Around the World: Findings from GLOBE, 37, 1, 28-39. 


\section{Alysia Blackham}

Atchley, R. 1982. Retirement as a social institution. Annual Review of Sociology, 8, 263-87.

Avsar, R. B. 2014. Foreclosure crisis and innovative policy responses: a constructive critique. Journal of Economic Issues, 48, 1, 155-68.

Bartanen, M. 1982. The role of values in policy controversies. Contemporary Argumentation Eं Debate, 3, 19-24.

Bengtson, V. L. and Oyama, P. S. 2010. Intergenerational solidarity and conflict. In Cruz-Saco, M. A. and Zelenev, S. (eds), Intergenerational Solidarity: Strengthening Economic and Social Ties. Palgrave Macmillan, New York, 35-52.

Bernard, M. and Phillips, J. 2000. The challenge of ageing in tomorrow's Britain. Ageing E Society, 20, 1, 33-54.

Bettio, F., Tinios, P. and Betti, G. n.d. The gender gap in pensions in the EU. FGBFondazione Giacomo Brodolini, Rome.

Bisom-Rapp, S. and Sargeant, M. 2011. Increasing the employment rate of older workers. International Journal of Comparative Labour Law and Industrial Relations, 27, 3, 301-14.

Blackham, A. 2016. Extending Working Life for Older Workers: Age Discrimination Law, Policy and Practice (Hart, Oxford, in press).

Boltanski, L. and Thévenot, L. 20o6. On Justification: Economies of Worth. Princeton University Press, Princeton, New Jersey.

Butts, D. M. 2010. Key issues uniting generations. In Cruz-Saco, M. A. and Zelenev, S. (eds), Intergenerational Solidarity: Strengthening Economic and Social Ties. Palgrave Macmillan, New York, 84-97.

Camillus, J. C. 2008. Strategy as a wicked problem. Harvard Business Review, 86, 5, $9^{8-106 .}$

Charmaz, K. 2006. Constructing Grounded Theory: A Practical Guide Through Qualitative Analysis. Sage, London.

Clark, P. G. 1993. Moral discourse and public policy in aging: framing problems, seeking solutions, and 'public ethics'. Canadian Journal on Aging/La Revue canadienne du vieillissement, 12, $4,4^{8} 5^{-} 5^{\text {o8 }}$.

Collins, H. 2003. Discrimination, equality and social inclusion. The Modern Law Review, 66, 1, 16-43.

Crawford, J. O., Graveling, R. A., Cowie, H. A. and Dixon, K. 2010. The health safety and health promotion needs of older workers. Occupational Medicine, 6o, 3, 184-92.

Croucher, R. and Kelliher, C. 2005. The right to request flexible working in Britain: the law and organisational realities. International Journal of Comparative Labour Law and Industrial Relations, 2 1, 3, 503-20.

Cruz-Saco, M. A. 2010. Intergenerational solidarity. In Cruz-Saco, M.A. and Zelenev, S. (eds), Intergenerational Solidarity: Strengthening Economic and Social Ties. Palgrave Macmillan, New York, 9-34.

D'Addio, A. C., Keese, M. and Whitehouse, E. 2010. Population ageing and labour markets. Oxford Review of Economic Policy, 26, 4, 613-35.

Daly, M. 2011. What adult worker model? A critical look at recent social policy reform in Europe from a gender and family perspective. Social Politics: International Studies in Gender, State $\mathcal{E}$ Society, 18, 1, 1-23.

Dean, M. 2010. Governmentality: Power and Rule in Modern Society. Second edition, Sage, London.

Dean, M. 2014. Rethinking neoliberalism. Journal of Sociology, 5o, 2, $150-63$.

Department for Culture, Media and Sport and Government Equalities Office 2013. Creating a Fairer and More Equal Society. Inside Government. Available online at https://www.gov.uk/government/policies/creating-a-fairer-and-more-equal-society [Accessed 22 July 2013]. 
Department for Work and Pensions (DWP) 2009a. Building a Society for All Ages. DWP, London.

Department for Work and Pensions (DWP) 2009b. Report on Implementation of Opportunity Age Commitments. Available online at http://www.dwp.gov.uk/docs/ opp-age-commitments-pres.pdf [Accessed 18 December 2012].

Department for Work and Pensions (DWP) 2013. Improving Opportunities for Older People. Available online at https://www.gov.uk/government/policies/improvingopportunities-for-older-people [Accessed 22 July 2013].

Department for Work and Pensions (DWP) 2014a. A Powerful New Voice for Older Workers. Available online at https://www.gov.uk/government/news/a-powerfulnew-voice-for-older-workers [Accessed 25 August 2014].

Department for Work and Pensions (DWP) 2014 b. Fuller Working Lives: A Framework for Action. Available online at https://www.gov.uk/government/publications/ fuller-working-lives-a-framework-for-action [Accessed 9 July 2014].

Department for Work and Pensions (DWP) 2015. Help and Support for Older Workers. Available online at https://www.gov.uk/government/publications/help-andsupport-for-older-workers/help-and-support-for-older-workers\#employment-supportfor-the-over-5os [Accessed 26 October 2015].

Department of Business, Innovation and Skills (BIS) 2010. Phasing Out the Default Retirement Age: Consultation Document. Available online at http://www.bis.gov.uk/ assets/biscore/employment-matters/docs/p/10-1047-default-retirement-ageconsultation.pdf [Accessed 26 April 2012].

Department of Business, Innovation and Skills (BIS) 2011 a. Flexible, Effective, Fair: Promoting Economic Growth Through a Strong and Efficient Labour Market. BIS, London.

Department of Business, Innovation and Skills (BIS) $2011 \mathrm{~b}$. Phasing Out the Default Retirement Age: Government Response to Consultation. BIS, London.

Department of Trade and Industry (DTI) 2003. Equality and Diversity: Age Matters. Available online at http://webarchive.nationalarchives.gov.uk/+/http://www. berr.gov.uk/files/file24331.pdf [Accessed 1 February 2012].

Department of Trade and Industry (DTI) 2005. Equality and Diversity Coming of Age: Consultation on the Draft Employment Equality (Age) Regulations 20o6. Available online at http://webarchive.nationalarchives.gov.uk/+/http://www.berr.gov.uk/files/ file 26479.pdf [Accessed 1 February 2012].

Diepeveen, S. 201 2. Impact of the Recession on Age Management Policies: United Kingdom. Available online at http://www.eurofound.europa.eu/pubdocs/2011/755/en/ 1/EF11755EN.pdf [Accessed 9 March 2012].

Dobrowolsky, A. Z. and Jenson, J. 2004. Shifting representations of citizenship: Canadian politics of 'women' and 'children'. Social Politics: International Studies in Gender, State and Society, 11, 2, 154-80.

Dorfman, M. and Palacios, R. 201 2. World Bank support for pensions and social security. Working Paper, World Bank, Washington DC.

Ebbinghaus, B. and Whiteside, N. 2012. Shifting responsibilities in Western European pension systems: what future for social models? Global Social Policy, 12, 3, 266-82.

Estes, C. L. 2001. Social Policy E Aging. Thousand Oaks, Sage, California.

Eurofound 2012. Foundation Findings: Intergenerational Solidarity. Eurofound, Luxembourg.

European Commission 2011a. Active Ageing and Solidarity Between Generations: A Statistical Portrait of the European Union 2OI2. Publications Office of the European Union, Luxembourg. 
European Commission 2011 b. The 2012 Ageing Report: Underlying Assumptions and Projection Methodologies. European Economy, Brussels.

European Commission 2013. Ageing - Policy. Public Health. Available online at http:// ec.europa.eu/health/ageing/policy/index_en.htm [Accessed 5 September 2013].

Flynn, M., Schröder, H., Higo, M. and Yamada, A. 2014. Government as institutional entrepreneur: extending working life in the UK and Japan. Journal of Social Policy, $43,3,535^{-53}$.

Fredman, S. 2002. Discrimination Law. Oxford University Press, Oxford.

Fredman, S. 2003. The age of equality. In Fredman, S. and Spencer, S. (eds), Age as an Equality Issue: Legal and Policy Perspectives. Hart, Oxford, 2 1-69.

Fredman, S. 2011. Discrimination Law. Second edition, Oxford University Press, Oxford.

Fredman, S. and Spencer, S. (eds) 2003. Age as an Equality Issue. Hart, Oxford.

Frericks, P. R. H. and Maier, R. M. 2008. Pension norms and pension reforms in Europe - the effects on gender pension gaps. Community, Work $\mathcal{E}$ Family, 11, 3, $253-71$.

Giacomini, M., Hurley, J., Gold, I., Smith, P. and Abelson, J. 2001. Values in Canadian Health Policy Analysis: What Are We Talking About. Canadian Health Services Research Foundation, Ontario. Available online at http://www.fcass-cfhi.ca/ Migrated/PDF/ResearchReports/OGC/giacomini_final.pdf [Accessed 22 August 2014 ].

Government Actuary's Department 2010. Government Actuary's Quinquennial Review of the National Insurance Fund as at April 2005. Available online at http://www. gad.gov.uk/Documents/Social\%2oSecurity/Quinquennial_Review_10-Full_Report. pdf [accessed 24 March 2012].

Government Equalities Office 2008. Framework for a Fairer Future- The Equality Bill. Government Equalities Office, London.

Gray, J. 200o. Inclusion: a radical critique. In Askonas, P. and Stewart, A. (eds), Social Inclusion: Possibilities and Tensions. Macmillan, Basingstoke, UK, 19-36.

Grech, A. G. 2013. How Best to Measure Pension Adequacy. Centre for Analysis of Social Exclusion, London.

Guillemard, A.-M. and Rein, M. 1993. Comparative patterns of retirement: recent trends in developed societies. Annual Review of Sociology, 19, 469-503.

Harris, J. 2006. The roots of public pensions provision: social insurance and the Beveridge plan. In Pemberton, H., Thane, P. and Whiteside, N. (eds), Britain's Pensions Crisis: History and Policy. Oxford University Press, Oxford, 27-38.

Hepple, B. 2013. Back to the future: employment law under the Coalition government. Industrial Law Journal, 42, 3, 203-23.

Hepple, B. A. 2011 . Equality: The New Legal Framework. Hart, Oxford.

HM Government 2005. Opportunity Age: Meeting the Challenges of Ageing in the 2 Ist Century. HM Government, London.

HM Government 2008. Preparing for Our Ageing Society: A Discussion Paper. Available online at https://www.gov.uk/government/publications/preparing-for-our-ageingsociety-a-discussion-paper [Accessed 13 July 2014 ].

HM Government 2010. The Equality Strategy-Building a Fairer Britain. HM Government, London.

HM Government 201 2. The Equality Strategy - Building a Fairer Britain: Progress Report. Available online at https://www.gov.uk/government/publications/the-equalitystrategy-building-a-fairer-britain-progress-report [Accessed 26 October 2015].

HM Government 2013. Government Response to the House of Lords Select Committee on Public Service and Demographic Change Report of Session 2OI 2-I3: 'Ready for Ageing?' HM Government, London. 
HM Treasury 2008. Lisbon Strategy for Jobs and Growth: UK National Reform Programme. HM Treasury, London.

Hofstede, G. 2001. Culture's Consequences: Comparing Values, Behaviors, Institutions, and Organizations Across Nations. Second edition, Sage, Thousand Oaks, California.

Izuhara, M. 2010. Introduction. In Izuhara, M (ed.), Ageing and Intergenerational Relations: Family Reciprocity from a Global Perspective. Ageing and the Lifecourse. Policy Press, Bristol, UK, 1-12.

Jenson, J. 1989. Paradigms and political discourse: protective legislation in France and the United States before 1914. Canadian Journal of Political Science, 22, 2, 235-58.

Jessop, B. 1997. The governance of complexity and the complexity of governance: preliminary remarks on some problems and limits of economic guidance. In Amin, A. and Hausner, J. (eds), Beyond Market and Hierarchy: Interactive Governance and Social Complexity. Edward Elgar, Cheltenham, UK, 95-128.

Karppinen, K. and Moe, H. 2014. What we talk about when we talk about 'the market': conceptual contestation in contemporary media policy research. Journal of Information Policy, 4, 327-41.

Kirton, G. and Greene, A. 2010. The Dynamics of Managing Diversity: A Critical Approach. Third edition, Elsevier, Oxford.

Krippendorff, K. 2013. Content Analysis: An Introduction to its Methodology. Third edition, Sage, Los Angeles.

Levitas, R. 2005. The Inclusive Society? Social Exclusion and New Labour. Second edition, Palgrave Macmillan, Basingstoke, UK.

Lister, R. 2000. Strategies for social inclusion: promoting social cohesion or social justice. In Askonas, P. and Stewart, A. (eds), Social Inclusion: Possibilities and Tensions. Macmillan, Basingstoke, UK, $37-54$.

Loretto, W., Vickerstaff, S. and White, P. 2005. Older workers and options for flexible work. EOC Working Paper, Equal Opportunities Commission, Manchester, UK.

Loretto, W., Vickerstaff, S. and White, P. (eds) 2009. The Future for Older Workers: New Perspectives. Policy Press, Bristol, UK.

Lowenstein, A. 2010. Determinants of the complex interchange among generations: collaboration and conflict. In Cruz-Saco, M. A. and Zelenev, S. (eds), Intergenerational Solidarity: Strengthening Economic and Social Ties. Palgrave Macmillan, New York, 53-80.

Malleson, K. 2009. Diversity in the judiciary: the case for positive action. Journal of Law and Society, 36, 3, 376-402.

Muchmore, L., Lynch, W. D., Gardner, H. H., Williamson, T. and Burke, T. 2003. Prevalence of arthritis and associated joint disorders in an employed population and the associated healthcare, sick leave, disability, and workers' compensation benefits cost and productivity loss for employers. Journal of Occupational and Environmental Medicine, 45, 4, 369-78.

O'Cinneide, C. 2011 . The uncertain foundations of contemporary anti-discrimination law. International Journal of Discrimination and the Law, 11, 1/2, 7-28.

Office for National Statistics (ONS) 2011. UK Population Projected to Reach 7o Million by Mid-2027. Available online at http://www.ons.gov.uk/ons/rel/npp/nationalpopulation-projections/2010-based-projections/sum-201o-based-national-populationprojections.html [Accessed 7 December 2011].

Office for National Statistics (ONS) 2012. Older Workers in the Labour Market, 2012. Office for National Statistics, London.

Patton, M. Q. 1990. Qualitative Evaluation and Research Methods. Second edition, Sage, Newbury Park, California. 
Performance and Innovation Unit 200o. Winning the Generation Game: Improving Opportunities for People Aged 50-65 in Work and Community Activity. Performance and Innovation Unit, London.

Phillipson, C. 1987. The transition to retirement. In Cohen, G. (ed.), Social Change and the Life Course. Tavistock Publications, London, $15^{6-83}$.

Phillipson, C. 2002. Transitions from Work to Retirement: Developing a New Social Contract. Available online at http://www.jrf.org.uk/sites/files/jrf/jr133-transitions-workretirement.pdf [Accessed 19 March 2012].

Posner, R. 1995. Aging and Old Age. University of Chicago Press, Chicago.

Riley, M. W. 1988. The aging society: problems and prospects. Proceedings of the American Philosophical Society, 132, 2, 148-53.

Riley, M. W. and Riley Jr, J. W. 1994. Age integration and the lives of older people. The Gerontologist, 34, 1, $110-5$.

Rittel, H. W. J. and Webber, M. M. 1973. Dilemmas in a general theory of planning. Policy Sciences, 4, 2, $155^{-69 .}$

Ryan, G. W. and Bernard, H. R. 2003. Data management and analysis methods. In Denzin, N. K. and Lincoln, Y.S. (eds), Collecting and Interpreting Qualitative Materials. Second edition, Sage, Thousand Oaks, California, 259-309.

Sargeant, M. 2004. Mandatory retirement age and age discrimination. Employee Relations, 26, $1 / 2,151$.

Sargeant, M. 2006. The Employment Equality (Age) Regulations 2006: a legitimisation of age discrimination in employment. Industrial Law Journal, 35, 3, 209-27.

Sargeant, M. (ed.) 2008. The Law on Age Discrimination in the EU. Kluwer Law International, Alphen aan den Rijn, The Netherlands.

Schiek, D. 2011. Age discrimination before the ECJ-conceptual and theoretical issues. Common Market Law Review, 48, 3, 777-99.

Schram, S. 1999. After Welfare: The Culture of Postindustrial Social Policy. New York University Press, New York.

Schwartz, B. 1993. On the creation and destruction of value. In Hechter, M., Nadel, L. and Michod, R. E. (eds), The Origin of Values. Sociology and Economics. Aldine de Gruyter, New York, 153-86.

Select Committee on Public Service and Demographic Change 2013. Ready for ageing? Report of Session 2012-13, Select Committee on Public Service and Demographic Change, London.

Social Exclusion Unit 2006. A Sure Start to Later Life: Ending Inequalities for Older People. Social Exclusion Unit, London.

Soss, J., Fording, R. C. and Schram, S. 2011 . Disciplining the Poor: Neoliberal Paternalism and the Persistent Power of Race. University of Chicago Press, Chicago.

Stewart, A. 200o. Social inclusion: an introduction. In Askonas, P. and Stewart, A. (eds), Social Inclusion: Possibilities and Tensions. Macmillan, Basingstoke, UK, 1-16.

Supiot, A. 2007. Homo Juridicus: On the Anthropological Function of the Law. Verso, London.

Thacher, D. and Rein, M. 2004. Managing value conflict in public policy. Governance, 17, 4, 457-86.

Thévenot, L. 2011 . Conventions for measuring and questioning policies. The case of $5^{\mathrm{o}}$ years of policy evaluations through a statistical survey. Historical Social Research/ Historische Sozialforschung, 36, 4, 192-2 17.

van Deth, J. W. and Scarbrough, E. 1998. The concept of values. In van Deth, J. W. and Scarbrough, E. (eds), The Impact of Values. Beliefs in Government. Oxford University Press, Oxford, 21-47. 
van Hoecke, M. 2011 . Legal doctrine: which method(s) for what kind of discipline? In van Hoecke, M. (ed.), Methodologies of Legal Research: What Kind of Method for What Kind of Discipline? European Academy of Legal Theory, Hart, Oxford, 1-18.

Vickers, L. and Manfredi, S. 2013. Age equality and retirement: squaring the circle. Industrial Law Journal, 42, 1, 61-74.

Vickerstaff, S., Cox, J. and Keen, L. 2003. Employers and the management of retirement. Social Policy E Administration, 37, 3, 271-87.

von Nordheim, F. 2004. Responding well to the challenge of an ageing and shrinking workforce: European Union policies in support of member state efforts to retain, reinforce and re-integrate older workers in employment. Social Policy and Society, 3, 2, 145-53.

Weber, R. P. 1990. Basic Content Analysis. Quantitative Applications in the Social Sciences. Second edition, Sage, Newbury Park, California.

Webley, L. 2010. Qualitative approaches to empirical legal research. In Cane, P. and Kritzer, H. M. (eds), The Oxford Handbook of Empirical Legal Research. Oxford University Press, Oxford, 926-50.

Weitzman, E. A. 2003. Software and qualitative research. In Denzin, N. K. and Lincoln, Y.S. (eds), Collecting and Interpreting Qualitative Materials. Second edition, Sage, Thousand Oaks, California, 310-39.

Weller, S. A. 2007. Discrimination, labour markets and the labour market prospects of older workers: what can a legal case teach us? Work, Employment $\mathcal{E}^{2}$ Society, 2 1, 3, 417-37.

Williams, A. T. 2010. Promoting justice after Lisbon: groundwork for a new philosophy of EU law. Oxford Journal of Legal Studies, 3o, 4, 663-93.

Yanow, D. 1992. Silences in public policy discourse: organizational and policy myths. Journal of Public Administration Research and Theory, 2, 4, 399-423.

Accepted 26 February 20I6; first published online 20 April 2 о I 6

Address for correspondence:

Alysia Blackham,

Melbourne Law School,

The University of Melbourne,

Victoria 3010, Australia

E-mail: alysia.blackham@unimelb.edu.au 